\title{
PEMBELAJARAN BERBASIS RISET MEWUJUDKAN PEMBELAJARAN YANG INSPIRATIF
}

\author{
Slameto \\ slameto@staff.uksw.edu \\ FKIP - Universitas Kristen Satya Wacana
}

\begin{abstract}
ABSTRAK
Tuntutan terhadap proses pembelajaran yang berkualitas semakin tinggi seiring dengan perkembangan dan perubahan zaman. Proses pembelajaran pada setiap satuan pendidikan harus inspiratif; Kuncinya adalah bagaimana proses pembelajaran lebih bersifat kontekstual dan saintifik sehingga membentuk karakter peserta didik yang berjiwa saintis (ilmuwan). Sayangnya guru yang siap untuk itu adalah guru yang inspiratif yang menurut Rhenald Kasali (2007) jumlanya kurang dari $1 \%$. Setelah setengah abad melakukan advokasi, Paul A. Kirschner, John Sweller, dan Richard E. Clark (2006) menemukan banyak kelemahan pembelajaran kunstruktif yang student centered sehingga tidak efektif; tidak ada penelitian yang mendukung efektifitas teknik ini. Sejauh ini tidak ada bukti dari studi yang terkendali, yang menunjukan pembelajaran berbasis konstruktivistik yang berhasil; biasanya kurang efektif; bahkan negatif. Seiring gencarnya semangat pemerintah menerapkan pembelajaran saintifik melalui kurikulun nasional muncul permasalahan bagaimana menghasilkan pengajaran yang inspiratif, apakah pembelajaran saintifik atau berbasis riset yaitu: Aktive Learning, Inquiry-Based Learning, Problem-Based Learning, dan Peer Instruction mampu mewujudkan pembelajaran efektif yang inspiratif? Penelitian ini menggunakan studi dokumen atas hasil-hasil penelitian sebelumnya. Pengumpulan data dilakukan dengan menelusuri jurnal elektronik melalui Google Cendekia. Dari hasil penelusuran yang diperoleh, masing-masing model dipilih 2 hasil penelitian untuk dianalisis lebih lanjut dalam bentuk \%. Berdasarkan hasil analisis ternyata 4 pembelajaran berbasis riset (yang inspiratif secara implisit) mampu meningkatkan hasil belajar, mulai dari yang terendah $8 \%$ sampai yang tertinggi $35 \%$ dengan rata-rata $18,45 \%$.
\end{abstract}

Kata Kunci: Aktive Learning, Inquiry-Based Learning, inspiratif, Peer Instruction, Pembelajaran Berbasis Riset, Problem-Based Learning.

\section{PENDAHULUAN}

Tuntutan terhadap proses pembelajaran yang berkualitas semakin tinggi seiring dengan perkembangan dan perubahan zaman. Mengingat kebhinekaan budaya, keragaman latar belakang dan karakteristik peserta didik, serta tuntutan untuk menghasilkan lulusan yang bermutu, proses pembelajaran untuk setiap mata pelajaran harus fleksibel, bervariasi, dan memenuhi standar proses (Permendiknas no 41 tahun 2007 tentang Standar Proses Pembelajaran). Standar proses berisi kriteria minimal proses pembelajaran pada satuan pendidikan dasar dan menengah di seluruh wilayah hukum Negara Kesatuan Republik Indonesia. Lebih lanjut ditegaskan bahwa proses pembelajaran pada setiap satuan pendidikan dasar dan menengah untuk terlaksananya proses pembelajaran yang efektif dan efisien harus: 
interaktif, inspiratif, menyenangkan, menantang, dan memotivasi peserta didik untuk berpartisipasi aktif, serta memberikan ruang yang cukup bagi prakarsa, kreativitas, dan kemandirian sesuai dengan bakat, minat, dan perkembangan fisik serta psikologis peserta didik. Maka dari itu, proses pembelajaran yang dilaksanakan dalam pendidikan diharapkan mampu mencetak lulusan-lulusan yang memiliki karakter mulia, keterampilan-keterampilan yang relevan, dan pengetahuan-pengetahuan yang terkait. Untuk itu proses pembelajaran yang terlaksana harus melibatkan keaktifan siswa secara maksimal baik dengan pendekatan teacher centered learning maupun student centered learning. Kuncinya adalah bagaimana proses pembelajaran lebih bersifat kontekstual, saintifik dan adanya kesesuaian antara kompetensi, materi dan sistem penilaian yang dilaksanakan (kurikulum 2013).

Riset (penelitian) sebagai proses penyelidikan atau pencarian yang saksama untuk memperoleh fakta baru dalam cabang ilmu pengetahuan merupakan konsep yang tepat untuk diterapkan dalam pembelajaran. Dengan penerapan pendekatan pembelajaran berbasis riset diharapkan karakter yang terbentuk dalam diri peserta didik adalah jiwa seorang saintis (ilmuwan). Sikap tersebut ditandai dengan sikap rasa ingin tahu yang tinggi, mampu menyelesaikan setiap permasalahan, dengan sikap berpikir secara sistematis, objektif, dan memiliki dasar pemikiran yang kuat. Proses pembelajaran dengan pendekatan pembelajaran berbasis riset adalah pembelajaran yang menuntut peserta didik untuk mampu menemukan, mengeksplorasi (mengembangkan pengetahuan) untuk menyelesaikan masalah yang dihadapi, dan kemudian menguji kebenaran pengetahuan tersebut. Adapun interaksi pembelajaran antara peserta didik dengan pendidik adalah interaksi yang bersifat aktif. Pendidik berperan sebagai fasilitator, dan mediator dalam rangka membawa peserta didik untuk mencapai kompetensi yang diharapkan (Sigit Mangun Wardoyo, 2013).

Setelah setengah abad melakukan advokasi terkait dengan pembelajaran menggunakan panduan minimal yang didasari aliran kunstruktif yang student centered, tampak bahwa banyak kelemahan sehingga tidak efektif; Tidak ada penelitian yang mendukung efektifitas teknik ini. Sejauh ini tidak ada bukti dari studi yang terkendali, bahwa bimbingan pembelajaran yang minimal (student centered, berbasis konstruktivistik bagi siswa pendidikan dasar atau menengah) yang berhasil. Bahkan untuk siswa dengan pengetahuan awal yang cukup sekalipun, tenyata sama-sama efektif dalam pembelajaran yang menerapkan bimbingan minimal (student centered) maupun yang dilaksanakan dengan bimbingan guru lebih banyak (teacher centered). Khusus pembelajaran student centered, biasanya kurang efektif; bahkan ada juga bukti hasil yang negatif ketika siswa memperoleh pahaman yang salah, atau tidak lengkap atau tidak teratur pengetahuannya itu (Paul A. Kirschner, John Sweller, Richard E. Clark, 2006).

Menurut Rhenald Kasali (2007) ada dua jenis guru yang kita kenal yaitu guru kurikulum dan guru Inspiratif. Guru kurikulum sangat patuh pada kurikulum dan merasa berdosa bila tidak bisa mentransfer semua isi buku yang ditugaskan. Ia mengajarkan sesuatu yang standar (habitual thinking) dan jumlahnya sekitar 99\%. Sedangkan guru inspiratif jumlanya kurang dari $1 \%$. Ia bukan guru yang mengejar kurikulum tetapi mengajak murid-muridnya berfikir kreatif (maximum thinking). Ia mengajak murid- 
muridnya melihat sesuatu dari luar (thinking out of box) mengubahnya di dalam, lalu membawa kembali keluar, ke masyarakat luas. Guru inspiratif melahirkan pemimpinpembaru yang berani menghancurkan aneka kebiasaan lama.

Proses pembelajaran diharapkan mampu mencetak lulusan-lulusan yang memiliki karakter mulia dan inspiratif, keterampilan-keterampilan yang relevan, dan pengetahuan-pengetahuan yang terkait. Oleh karena itu proses pembelajaran yang diharapkan mampu melibatkan keaktifan siswa secara maksimal baik dengan pendekatan teacher centered learning maupun student centered learning. Kuncinya adalah bagaimana proses pembelajaran yang diberikan lebih bersifat kontekstual dan adanya kesesuaian antara materi dan sistem penilaian yang dilaksanakan (Sigit Mangun Wardoyo, 2013).

Seiring gencarnya semangat pemerintah menerapkan pembelajaran saintifik melalui kurikulun nasional (penyempurnaan dari kurikulum 2013) mulai tahun ini, muncul permasalahan bagaimana menghasilkan guru yang inspiratif, apakah pembelajaran saintifik atau berbasis riset mampu mewujudkan pembelajaran yang inspiratif?

Dalam pembelajaran yang Teacher Centered Learning, pendidik lebih banyak melakukan kegiatan belajar-mengajar dengan bentuk yang didominasi ceramah. Pada saat mengikuti pelajaran atau mendengarkan ceramah, siswa sebatas memahami sambil membuat catatan, bagi yang merasa memerlukannya. Guru menjadi pusat peran dalam pencapaian hasil pembelajaran dan seakan-akan menjadi satu-satunya sumber ilmu. Model ini berarti memberikan informasi satu arah karena yang ingin dicapai adalah bagaimana guru bisa mengajar dengan baik sehingga yang ada hanyalah transfer penge-tahuan (Sudjana, D. 2005). Dengan demikian pendekatanteacher center proses pembelajaran lebih berpusat pada guru hanya akan membuat guru semakin cerdas tetapi siswa hanya memiliki pengalaman mendengar paparan saja. Out put yang dihasilkan oleh pendekatan belajar seperti ini tidak lebih hanya menghasilkan siswa yang kurang mampu mengapresiasi ilmu pengetahuan, takut berpendapat, tidak berani mencoba yang akhirnya cenderung menjadi pelajaran yang pasif dan miskin kreativitas (Kasinyo Hartato dan Abduramansyah. 2009).

Perubahan paradigma pembelajaran terjadi, karena tuntutan kondisi global (persaingan, persyaratan kerja, perubahan orientasi) sehingga terjadi perubahan kompetensi lulusan (perubahan kurikulum). Perubahan kurikulum juga berlatar belakang perubahan paradigma (pengetahuan, belajar dan mengajar). Akibat perubahan paradigma ini diharapkan ada perubahan perilaku pembelajaran, sehingga mampu meningkatkan mutu lulusan. Mengajar bukan lagi bagaimana guru mengajar dengan baik (teacher center), tetapi transfer of knowledge, sehingga terbentuk $\mathrm{p}$ embelajaran bagaimana siswa bisa belajar dengan baik dan berkelanjutan(student centered Learning yang disingkat SCL).

Pengertian student centered Learning (SCLdalah proses pembelajaran yang berpusat pada siswa (learner centered) diharapkan dapat mendorong siswa untuk terlibat secara aktif dalam membangun pengetahuan, sikap dan perilaku. Melalui proses pembelajaran yang keterlibatan siswa secara aktif, berarti guru tidak lagi mengambil hak seorang peserta didik untuk belajar. Aktifitas siswa menjadi penting ditekankan karena belajar itu pada hakikatnya adalah proses yang aktif dimana siswa 
menggunakan pikirannya untuk membangun pemahaman (construcivism approach) (Harto, kasinyo. 2012). Proses pembelajaran yang berpusat pada siswa atau peserta didik, maka siswa memperoleh kesempatan dan fasilitas untuk dapat membangun sendiri pengetahuannya sehingga mereka akan memperoleh pemahaman yang mendalam yang pada akhirnya dapat meningkatkan mutu kualitas siswa. Melalui penerapan pembelajaran yang berpusat pada siswa, siswa diharapkan dapat berpartisipasi secara aktif, selalu ditantang untuk memiliki daya kritis, mampu menganalisa dan dapat memecahkan masalahnya sendiri. Sistem Pembelajaran SCL dapatlah digambarkan seperti berikut ini.

Pembelajaran yang berlangsung di sekolah seyogyanya menerapkan prinsipprinsip teori kognitif-konstruktivistik serta teori pemodelan tingkah laku agar kemandirian aktif siswa sebagai pebelajar dapat diwujudkan (Arends, 1997). Pendidikan inspiratif adalah proses memanusiakan manusia yang diarahkan untuk terwujudnya insan-insan yang memiliki sifat mampu menjadi ilham atau memberikan dorongan orang lain, sehingga orang lain tergerak hatinya untuk berbuat. Perbuatan orang lain ini dapat berupa meniru atau meneladani sang inspirator atau memodifikasi hal-hal yang baru (M. Arifin Saputra, 2014). Proses pembelajaran yang inspiratif adalah proses pembelajaran pada setiap mata pelajaran yang mampu memberikan inspirasi, mampu membangkitkan rasa ingin tahu siswa, dan mampu menfasilitasi pengkonstruksian pengetahuan oleh siswa.

Riset merupakan sarana penting untuk meningkatkan mutu pembelajaran. Pendidik dapat memaparkan hasil penelitiannya sebagai contoh nyata dalam pembelajaran, yang diharapkan dapat berfungsi membantu peserta didik dalam memahami ide, konsep, dan teori dari penelitiannya. Dalam kegiatan ini nilai, etika, dan praktik penelitian yang sesuai dengan bidang ilmu yang diajarkan dapat disampaikan untuk memberikan inspirasi kepada siswa.

Pembelajaran berbasis riset (PBR) merupakan salah satu metode studentcentered learning (SCL) yang mengintegrasikan riset di dalam proses pembelajaran. PBR bersifat multifaset yang mengacu kepada berbagai macam metode pembelajaran. PBR memberi peluang/kesempatan kepada siswa untuk mencari informasi, menyusun hipotesis, mengumpulkan data, menganalisis data, dan membuat kesimpulan atas data yang sudah tersusun; dalam aktivitas ini berlaku pembelajaran dengan pendekatan "learning by doing".

Ada beberapa strategi dalam memadukan pembelajaran dan riset yang secara empirik, yaitu; (1) memperkaya bahan ajar dengan hasil penelitian pendidik, (2) menggunakan temuan-temuan penelitian mutakhir dan melacak sejarah, (3) memperkaya kegiatan pembelajaran dengan isu-isu penelitian kontemporer, (4) mengajarkan materi metode penelitian di dalam proses pembelajaran, (5) memperkaya proses pembelajaran dengan kegiatan penelitian dalam skala kecil, (6) memperkaya proses pembelajaran dengan melibatkan peserta didik dalam kegiatan, (7) memperkaya proses pembelajaran dengan mendorong peserta didik agar merasa, dan (8) memperkaya proses pembelajaran dengan nilai-nilai yang harus dimiliki oleh peneliti (Masri Kudrat Umar, dkk. 2011).

Salah satu strategi dalam memadukan pembelajaran dan riset yang secara empirik dapat dilakukan dengan memperkaya bahan ajar dengan hasil penelitian 
pendidik. Pada proses pembelajaran ini hasil penelitian pendidik digunakan untuk memperkaya bahan ajar. Pendidik dapat memaparkan hasil penelitiannya sebagai contoh nyata dalam pembelajaran, yang diharapkan dapat berfungsi membantu peserta didik memahami ide, konsep, dan teori. Dalam kegiatan ini nilai, etika, dan praktik penelitian yang sesuai dengan bidang studi/mata pelajaran yang diajarkan dapat disampaikan untuk memberikan inspirasi kepada siswa (Hafsah. 2015).

Dalam strategi memperkaya proses pembelajaran dengan nilai-nilai yang harus di- miliki oleh peneliti, nilai-nilai yang harus dimiliki oleh peneliti seharusnya perlu dipahami oleh didik. Nilai-nilai tersebut antara lain: objektivitas, penghargaan akan temuan penelitian, respek pada pandangan lain, toleransi terhadap ketidak-pastian, dan kemampuan analisis (Masri Kudrat Umar, dkk. 2011).

Pada dasarnya student-centered learning (SCL) diilhami oleh "Patrap Triloka" yang dimunculkan oleh Ki Hadjar Dewantoro sebagai nilai kearifan lokal. "Patrap Triloka" (Ing ngarso sung tulodho, Ing madyo mangun karso, Tut wuri andayani). Hal ini kemudian dikemas sebagai Student Teacher Aesthetic Role-sharing (STAR). STAR adalah suatu kegiatan pembelajaran yang bersifat kolaboratif, interaktif, dan kontekstual untuk membawa perserta didik dan pendidik dalam suatu hubungan/suasana akademik yang lebih erat dan serasi. Strategi STAR atau SCL Plus memiliki berbagai macam metode pembelajaran; salah satu di antaranya adalah research-based learning (RBL) atau pembelajaran berbasis riset (PBR). Ditinjau dari aspek interaksi sosial di dalam proses pembelajaran maka ciri-ciri STAR sangat sesuai dengan ciri utama PBR, yaitu "berpikir tentang sesuatu yang sedang dikerjakan, mengerjakan sesuatu yang sedang dipikirkan". Sementara itu, ditinjau dari aspek inspiratif, maka STAR merupakan "ruh" pembelajaran berbasis riset (PBR) (Diah Tri Widayati, dkk. 2010).

Doug Holton (2015) dalam mengkounter kritik negatif atas strategi pembelajaran berbasis riset, dengan menunjukkan hasil-hasil dari beberapa penelitian aktual yang menunjukkan besarnya manfaat dan yang memberi inspirasi, yaitu: Active Learning, Inquiry-Based Learning, ProblemBased Learning, dan Peer Instruction.

Pembelajaran "active learning" merupakan salah satu pendekatan pembelajaran yang berorientasi pada aktivitas peserta didik (student-centered learning yang disingkat SCL). Pembelajaran berorientasi pada aktivitas peserta didik mengandung pengertian bahwa sistem pembelajaran menempatkan peserta didik sebagai subyek didik yang aktif dan telah memiliki kesiapan untuk belajar. Oleh karena itu, setiap peristiwa pembelajaran menuntut keterlibatan intelektual-emosional peserta didik melalui asimilasi dan akomodasi kognitif untuk mengembangkan pengetahuan, tindakan serta pengalaman langsung dalam rangka membentuk ketrampilan (kognitif, motorik, dan sosial), penghayatan serta internalisasi nilai-nilai dalam pembentukan sikap (Ali Muhtadi, 2009). Dalam implementasinya model pembelajaran tersebut dapat dikembangkan ke dalam 8 tahap prosedur pembelajaran, yaitu: (1) orientasi, (2) pembentukan kelompok, (3) penugasan kerja kelompok, (4) eksplorasi, (5) presentasi materi dalam kelas, (6) pengecekan pemahaman dan pendalaman materi, (7) refleksi dan umpan balik, dan (8) evaluasi formatif. 
Inkuiri yang berarti mengadakan penyelidikan, menanyakan keterangan, melakukan pemeriksaan, menurut Gulo (2005) berarti pertanyaan atau pemeriksaan, penyelidikan. Dari pengertian tersebut, dapat disimpulkan bahwa pembelajaran IBL (inquiry based learning) merupakan suattu pembelajaran yang mampu melibatkan siswa langsung kedalam kehidupan nyata dengan melakukan penyelidikan sendiri makna dan tujuan dari suatu materi pembelajaran. Pembelajaran dengan pendekatan IBL mengusahakan agar siswa selalu aktif secara mental maupun fisik. Materi yang diberikan oleh guru bukan begitu saja diberitahukan dan diterima oleh siswa, tetapi siswa diusahakan sedemikian rupa sehingga mereka memperoleh berbagai pengalaman dalam rangka "menemukan sendiri" konsep-konsep yang direncanakan oleh guru (Nurhadi dan Senduk, 2003). Model ini memiliki lima langkah pembelajaran (Joyce \& Weil, dalam I Wayan Santyasa, 2007), yaitu: (1) menghadapkan masalah (menjelaskan prosedur penelitian, menyajikan situasi yang saling bertentangan), (2) menemukan masalah (memeriksa hakikat obyek dan kondisi yang dihadapi, memeriksa tampilnya masalah), (3) mengkaji data dan eksperimentasi (mengisolasi variabel yang sesuai, merumuskan hipotesis), (4) mengorganisasikan, merumuskan, dan menjelaskan, dan (5) menganalisis proses penelitian untuk memperoleh prosedur yang lebih efektif.

Problem-Based Learning tidak dirancang untuk membantu guru memberikan informasi sebanyak-banyaknya kepada peserta didik. Model ini dikembangkan untuk membantu peserta didik mengembangkan kemampuan berpikir, pemecahan masalah, keterampilan intelektual, belajar berperan berbagai orang dewasa melalui pelibatan peserta didik dalam pengalaman nyata atau simulasi dan menjadi selfregulated kearner (Insih Wilujeng, 2011). Problem-Based Learning (PBL) adalah suatu metoda pembelajaran di mana peserta didik sejak awal dihadapkan pada suatu masalah, kemudian diikuti oleh proses pencarian informasi yang bersifat studentcentered. Seven Jumps (7 langkah) pada PBL: 1) Menjelaskan istilah dan konsep, 2) Menetapkan kata kunci dan masalah, 3) Menganalisis masalah, 4) Menghubungkan atau menarik kesimpulan, 5) Merumuskan tujuan/sasaran pembelajaran, 6) Mengumpulkan informasi dan 7) Mensintesis dan menguji informasi baru.

Tutor Sebaya adalah suatu metode pembelajaran yang menunjuk beberapa orang siswa yang ditugaskan untuk membantu murid-murid tertentu yang mengalami kesulitan belajar. Bantuan yang diberikan oleh teman sebaya pada umumnya dapat memberikan hasil yang lebih baik. Hubungan antar murid terasa lebih dekat dibandingkan dengan hubungan antara murid dengan guru (Moh. Surya, 1985). Tutor sebaya adalah sebuah proses belajar dengan difasilitasi oleh satu orang siswa atau lebih untuk membimbing siswa sebayanya yang mengalami kesulitan dalam belajar, sehingga interaksi antar siswa akan tumbuh dinamis, penuh kasih sayang, disiplin, dan memiliki komitmen belajar yang tinggi (Trianto, 2007). Langkah-langkah pelaksanaan metode peer teaching: 1) Mengatur bahan ajar yang akan diberikan kepada peserta didik, 2) Mengidentifikasi topik untuk pelajaran yang akan diberikan berdasarkan kebutuhan peserta didik pada tahun ini; (metode Peer Teaching diakhir semester untuk mengulang kembali pembelajaran). 3) Guru membagi para peserta didikmenjadi beberapa kelompok, 4) Setiap kelompok memilih satu topik untuk didiskusikan disertai lembar kegiatan, 5) 
Guru bekerja dengan kelompok untuk memastikan bahwa beberapa keterampilan dasar dipelajari: seperti teknik bertanya dan menjawab. Komunikasi antar kelompok dan mengisi LKS, 6) Melengkapi pembelajaran dengan ICT - teks, gambar, applet, audio, video, dll. 7) 50 persen dinilai dari proses pembelajaran dan lembar kegiatan sertbagaimana mereka meningkatkan pembelajaran dan 50 persen dinilai dari cara mereka mempresentasikan hasil diskusi, 8) Mempersiapkan waktu untuk masing-masing kelompok mempresentasikannya didepan kelas, 9) Guru mengatur kelompok-kelompok peserta didik untuk melatih mereka mengajar di kelas. 10) Siapkan lembar komentar untuk memungkinkan peserta didikuntuk memberikan kritik yang membangun kepada kelompok (Tan Tee Hwa, 2009).

\section{METODE}

Penelitian ini menggunakan studi dokumen atas hasil-hasil penelitian sebelumnya. Pengumpulan data dalam penelitian ini dilakukan dengan menelusuri jurnal pada beberapa media elektronik seperti digital library, internet, maupun koleksi jurnal perpustakaan. Penelusuran jurnal dilakukan melalui Google Cendekia. Kata kunci yang digunakan untuk penelusuran jurnal adalah: research based teaching, Active Learning, Inquiry-Based Learning, Problem-Based Learning, dan Peer Instruction. Dari hasil penelusuran diperoleh, dipilih yang memenuhi kriteria yaitu tersedianya data sebelum tindakan dan sesudahnya dalam bentuk skor. Dari masing-masing model dipilih 2 hasil penelitian untuk dianalisis lebih lanjut. Analisis menggunakan metode pembandingan untuk menentukan dampak penerapan model pembelajaran berbasis riset, selisih skor sebelum tindakan dengan sesudah tindakan sebagai besarnya peningkatan, kemudian dibagi dengan skor sebelum tindakan (dalam bentuk \%) untuk menentukan besarnya pengaruh tindakan pembelajaran terhadap hasil belajar.

\section{HASIL PENELITIAN DAN PEMBAHASAN}

Dengan cara melakukan browsing dengan google cendekia, diperoleh hasil penelitian seperti berikut ini. Research based teaching melalui Aktive Learning, diperoleh 42 hasil penelitian yang diterbitkan di Jurnal Nasional; Dari 42 hasil penelitian itu dipilih: Saifullah-NIM, A. R. I. F. (2010) dan Renteta, R., Rapani, R., \& Khair, A. (2014). Research based teaching melalui Inquiry-Based Learning, diperoleh 4 hasil penelitian yang diterbitkan di Jurnal Nasional; Dari 4 hasil penelitian itu dipilih: Atika, D. S., Sahputra, R., \& Hadi, L. (2016) dan Sumiarta, I. M. (2013). Research based teaching melalui Problem-Based Learning, diperoleh 4 hasil penelitian yang diterbitkan di Jurnal Nasional; Dari 4 hasil penelitian itu dipilih: Pratiwi, Y., Redjeki, T., \& Masykuri, M. (2014) dan Wulandari, B., \& Surjono, H. D. (2013). Research based teaching melalui dan Peer Instruction diperoleh 6 hasil penelitian yang diterbitkan di Jurnal Nasional; Dari 6 hasil penelitian itu dipilih: Ulfah, M. (2012) dan Sari, S. W., Yuliasma, Y., \& Desfiarni, D. (2013).

Mendasarkan hasil pencarian yg dilakukan menggunakan Google Cendekia terseleksi seperti di atas, hasil analisis terkait research based teaching melalui Aktive Learning, Inquiry-Based Learning, ProblemBased Learning, dan Peer Instruction dapat diperiksa pada tabel berikut ini. 
Tabel 1 Besarnya peningkatan hasil belajar sebagai pengaruh pembelajaran berbasis riset

\begin{tabular}{|c|c|c|c|c|c|c|}
\hline \multirow{2}{*}{ No } & \multirow{2}{*}{ Pembelajaran } & \multirow{2}{*}{ Peneliti } & \multicolumn{4}{|c|}{ Peningkatan hasil belajar } \\
\hline & & & Semula & Sesudah & Gain & Gain (\%) \\
\hline \multirow[t]{2}{*}{1} & Aktive Learning & Saifulah & 69,26 & 76,60 & 7,34 & 11 \\
\hline & & Renteta, R. & 69,67 & 78,00 & 8,33 & 12 \\
\hline \multirow[t]{2}{*}{2} & Inquiry-Based Learning & Atika, D. S & 78,50 & 84,40 & 5,90 & 8 \\
\hline & & Sumiarta & 62,75 & 84,70 & 21,95 & 35 \\
\hline \multirow[t]{2}{*}{3} & Problem-Based Learning & Pratiwi & 75 & 81,25 & 6,25 & 8 \\
\hline & & Wulandari & 73,84 & 89,09 & 15,25 & 21 \\
\hline \multirow[t]{2}{*}{4} & Peer Instruction & Ulfah & 73,68 & 94,73 & 21,05 & 29 \\
\hline & & Sari, S. Dkk. & 68 & 85 & 17,00 & 25 \\
\hline 5 & Pembelajaran berbasis riset & & 71,3375 & 84,2213 & 12,8837 & 18,45 \\
\hline
\end{tabular}

Berdasarkan hasil analisis yang tersaji pada Tabel 1 di atas, ternyata semua pembelajaran yang terhimpun dalam Pembelajaran Berbasis Riset mampu meningkatkan hasil belajar, mulai dari yang terendah $8 \%$ sampai yang tertinggi 35\% (inquiri based learning), dengan rata-rata $18,45 \%$.

Seperti tersaji pada tabel 1 , pembelajaran aktif memberi sumbangan kenaikan hasil belajar 11-12\%; Temuan ini pasti menyanggah temuan Paul A. Kirschner, John Sweller, Richard E. Clark, (2006), sesuai namanya saja pembelajaran aktif, sehingga dominasi peran ada pada siswa. "Penelitian mereka telah menunjukkan bahwa pendekatan siswa sebagai peserta aktif meningkatkan retensi keterampilan informasi dan pemikiran kritis dan secara signifikan dapat meningkatkan minat dan ketekunan yang tinggi terhadap Science, Technology, Engineering and Mathematics (STEM), dibandingkan dengan pembelajaran konvensional. Dalam studi lain, siswa pelajaran IPA yang menggunakan metode pembelajaran aktif, mereka belajar dua kali lebih banyak dibanding di kelas tradisional. Walaupun begitu menarik untuk dicermati, karena Paul sendiri menemukan bahwa 55\% tingkat kegagalan pembelajaran konvensional untuk meningkatkan keaktifan siswa. Hal ini bisa saja terjadi sesuai temuannya yang mana dalam pembelajaran konstruktif yang student Centered akan mengalami kegagalan juga sehingga tidak efektif mana kala siswa memperoleh pahaman yang salah, atau tidak lengkap atau tidak teratur pengetahuan terkait dengan materi maupun metode yang dikehendaki setiap model pembelajaran termasuk pembelajaran aktif.

Pembelajaran berbasis riset dalam bentuk IBL (inquiry based learning) mampu meningkatkan hasil belajar siswa 21,5\%; Paul A. Kirschner, John Sweller, Richard E. Clark, (2006) menyimpulkan bahwa kebanyakan guru yang (mengajar ilmu sesuai mata pelajaran) merasa bahwa pembelajaran berbasis riset, sifatnya memberikan nilai tambah yang begitu penting. Namun sebaliknya pembelajaran langsung (teacher centered), tidak menyebabkan pemahaman yang lebih baik tentang dasar-dasar ilmu yang dipelajarinya. Jika kedua mode mencakup aspek pengalaman dan aplikasi, dan jika penyelidikan difokuskan dan dipandu dengan baik maka benar bahwa pendidikan langsung 
(teacher centered) lebih efisien daripada 'penemuan terbuka/inkuiri based learning'.

Seperti hasil analisis yang tersaji pada tabel di atas, ternyata pembelajaran berbasis masalah mampu meningkatkan hasil belajar mulai dari $8 \%$ sampai $21 \%$. Model ini memang dikembangkan untuk membantu peserta didik mengembangkan kemampuan berpikir, pemecahan masalah, keterampilan intelektual, belajar berperan berbagai orang dewasa melalui pelibatan peserta didik dalam pengalaman nyata atau simulasi dan menjadi self-regulated kearner (Insih Wilujeng. 2011). Metoda pembelajaran ini sejak awal peserta didik dihadapkan pada suatu masalah, kemudian diikuti oleh proses pencarian informasi yang bersifat student-centered. Temuan menunjukkan bahwa PBL unggul ketika datang ke retensi jangka panjang, pengembangan keterampilan dan kepuasan siswa dan guru. Temuan ini jelas memberi koreksi atas temuan Paul A. Kirschner, John Sweller, Richard E. Clark (2006).

Tutor Sebaya adalah suatu metode pembelajaran yang menunjuk beberapa orang siswa yang ditugaskan untuk membantu murid-murid tertentu yang mengalami kesulitan belajar. Bantuan yang diberikan oleh teman sebaya pada umumnya dapat memberikan hasil yang lebih baik. Seperti hasil analisis pada tabel di atas, pembelajaran tutor sebaya mampu meningkatkan hasil belajar antara 25-29\%. Sehingga tidak tepatlah jika Paul A. Kirschner, John Sweller, Richard E. Clark (2006) menyatakan tidak ada penelitian yang mendukung efektifitas teknik ini; apalagi, sejauh ini tidak ada bukti dari studi yang terkendali, bahwa bimbingan pembelajaran yang minimal (student centered, berbasis konstruktivistik bagi siswa pendidikan dasar atau menengah) yang berhasil. Pada akhirnya, sangat menarik temuan Paul A. Kirschner, John Sweller, Richard E.
Clark, (2006) yang menyatakan bahwa ketika siswa memperoleh pemahaman yang salah, atau tidak lengkap atau tidak teratur pengetahuannya itu akan menjadi kendala serius bagi pengembangan inspirasi dalam pembelajaran, baik yang langsung atau teacher centered, apa lagi student centered.

\section{PENUTUP}

Proses pembelajaran pada setiap satuan pendidikan harus inspiratif; Kuncinya adalah bagaimana proses pembelajaran lebih bersifat kontekstual dan saintifik sehingga membentuk karakter peserta didik yang berjiwa saintis (ilmuwan). Sekalipun guru yang siap untuk itu adalah guru yang inspiratif yang menurut Rhenald Kasali (2007) jumlanya kurang dari $1 \%$, Pembelajaran yang kontekstual dan saintifik yaitu berbasis riset diharapkan mampu mewujudkan pembelajaran yang inspiratif

Pembelajaran saintifik atau berbasis riset yaitu: Aktive Learning, Inquiry-Based Learning, Problem-Based Learning, dan Peer Instruction mampu mewujudkan pembelajaran efektif yang inspiratif; mampu meningkatkan hasil belajar, mulai dari yang terendah $8 \%$ sampai yang tertinggi 35\% dengan rata-rata $18,45 \%$.

Dalam implementasinya, Pembelajaran berbasis riset ini sebetulnya bisa dilakukan secara langsung dengan bimbingan guru yang lebih banyak, mengingat siswa harus benar memahami materi dan prosedur pembelajaran yang benar untuk menghindaeri ketidakefektifan/kegagalan. Maka dari itu, peran guru memonitor dan memastikan siswa memperoleh pemahaman yang benar tentang materi maupun prosedur pembelajaran menjadi sangat penting dan menentukan keberhasilan siswa; Jika didapati siswa mengalami kesulitan, guru segera memberi pertolongan untuk solusinya (Slameto, 2016). 


\section{DAFTAR PUSTAKA}

Ali Muhtadi. 2009. Implementasi Konsep Pembelajaran "Active Learning" Sebagai Upaya Untuk Meningkatkan Keaktifan Mahasiswa Dalam Perkuliahan. Majalah Ilmiah Pembelajaran, Mei 2009.

Andayani. 2014. Modul Pembelajaran Berbasis Riset. Workshop Kurikulum Silabus \& Modul Pembelajaran Berbasis Riset Program Doktor dan Magister Pendidikan Bahasa Indonesia FKIP UNS. 19 Oktober 2014 Di Hotel Pramesthi Kartasura

Arends, Richard I. 1997. Classroom Instructional and Management. The McGraw- Hill Cpmpanies, Inc.

Atika, D. S., Sahputra, R., \& Hadi, L. 2016. Pengaruh Model Inkuiri Metode Praktikum Terhadap Sikap Ilmiah dan Hasil Belajar Kimia di SMA. Jurnal Pendidikan dan Pembelajaran, 54 (2).

Diah Tri Widayati; Djoko Luknanto; Edia Rahayuningsih; Gentur Sutapa; Harsono; Retno Peni Sancayaningsih; dan Sajarwa. 2010. Pedoman Umum Pembelajaran Berbasis Riset (PUPBR). Universitas Gadjah Mada

Doug Holton. 2015. Evidence for Various Research-based Instructional Strategies: Countering Critiques. https:// edtechdev.wordpress.com/2015/04/ 03/evidence-for-various-researchbased-instructional-strategiescountering-critiques/

Gulo,W. 2005. Strategi Belajar Mengajar. Jakarta: PT.Grasindo.

Hafsah. 2015. Implementasi Riset Based Learning dalam Upaya Peningkatan Kualitas Pembelajaran. Seminar Nasional Ekonomi Manajemen dan Akuntansi (SNEMA) Fakultas Ekonomi Universitas Negeri Padang. PadangIndonesia. http://fe.unp.ac.id/
I Wayan Santyasa, 2007. Model-Model Pembelajaran Inovatif. Makalah disajikan dalam pelatihan tentang Penelitian Tindakan Kelas bagi Guru-Guru SMP dan SMA di Nusa Penida,tanggal 29 Juni s.d 1 Juli 2007.

Insih Wilujeng. 2011. Mendesain Model Pembelajaran Inovatif Dan Inspiratif Menuju Keberhasilan Belajar Peserta Didik. Makalah Disampaikan Dalam Rangka Seminar "Inovasi Pembelajaran dan Hasil PTK' pada Tanggal 23-24 Nopember 2011 di Aula PSBB Man Yogyakarta III.

Kasinyo Hartato dan Abduramansyah. 2009. Metodologi Pembelajaran Berbasis Active Learni. Palembang: Grafika Telindo.

M. Arifin Saputra. 2014. Pendidikan Inspiratif Wujudkan Harapan Masa Depan yang Baik Pada Anak. http:// catatankecilanaknegeri.blogspot.co.id/ 2014/12/

Masri Kudrat Umar, dkk. 2011. Pengembangan Pembelajaran Berbasis Riset Di Program Studi Pendidikan Fisika FMIPA Universitas Negeri Gorontalo. Universitas Negeri Gorontalo

Nurhadi dan Senduk, Agus Gerrad. 2003. Pembelajaran Kontekstual (CTL) dan penerapannya dalam KBK. Malang: Universitas Negeri Malang.

Paul A. Kirschner, John Sweller, Richard E. Clark. 2006. Why Minimal Guidance During Instruction Does Not Work: An Analysis of the Failure of Constructivist, Discovery, Problem-Based, Experiential, and Inquiry-Based Teaching. Educational Psychologist, 41(2), 75-86

Peraturan Menteri Pendidikan Nasional Nomor 41 Tahun 2007 Tentang Standar Proses. 
Pratiwi, Y., Redjeki, T., \& Masykuri, M. 2014. Pelaksanaan Model Pembelajaran Problem Based Learning (PBL) pada Materi Redoks Kelas X SMA Negeri 5 Surakarta Tahun Pelajaran 2013/ 2014. Jurnal Pendidikan Kimia, 3 (3), 40-48.

Renteta, R., Rapani, R., \& Khair, A. 2014. Penerapan Active Learning Permainan Card Sort Untuk Meningkatkan Aktivitas dan Hasil Belajar. Jurnal Pedagogi, 2 (4).

Rhenald Kasali, 2007. Guru Kurikulum dan Guru Inspiratif. Kompas tanggal 29 Agustus 2007.

Saifullah-NIM, A. R. I. F. (2010). Penerapan Model Pembelajaran Aktif Tipe Pemilahan Kartu (Card Sort) untuk Meningkatkan Keaktifan dan Prestasi Belajar Siswa Kelas VII dalam Pembelajaran Fiqih Di MTs Tarbiyatul Islamiyah Pati (Doctoral dissertation, UIN Sunan Kalijaga Yogyakarta).

Sari, S. W., Yuliasma, Y., \& Desfiarni, D. 2013. Peningkatan Aktivitas Dan Hasil Belajar Tari dengan Menggunakan Metode Tutor Sebaya di SMP Negeri 4 Bukittinggi. Jurnal Sendratasik, 2(1), 22-29.

Seyra Winna Sari, Yuliasma, Desfiarni, 2013. Peningkatan Aktivitas dan Hasil Belajar Tari dengan Menggunakan Metode Tutor Sebaya di SMP Negeri 4 Bukittinggi. E-Jurnal Sendratasik FBS Universitas Negeri Padang. Vol 2 No 12013 Seri B.

Shimdt, F.L., \& Hunter, J.E. (1990). Methods of Meta Analysis. New York: Sage.
Sigit Mangun Wardoyo, 2013. Pembelajaran berbasis riset, Jakarta: Akademia.

Slameto, 2016. Pembelajaran Berbasis Riset Mewujudkan Pembelajaran yang Inspiratif? Prosiding Seminar Nasional menjadi guru inspirator. Universitas Muhammadiyah Purwokerto, 30 April, 2016.

Sudjana, D. 2005. Metoda dan Teknik Pembelajaran Partisipatif. Bandung: Falah Production .

Sumiarta, I. M. 2013. Pengaruh Model Pembelajaran Telaah Yurisprodensi Inquiri Terhadap Hasil Belajar PKN SD Kelas V Semester II Di Gugus IV Kecamatan Kintamani. MIMBAR $P G S D, 1$.

Surya, Muh., 1985, Psikologi Pendiddikan, Bandung: Fakultas Ilmu Pendidikan, IKIP.

Tan Tee Hwa. 2009. Student Peer Teaching Strategy, Bangkok: UNESCO

Trianto, 2007, Model-model pembelajaran Inovatif Berorientasi Konstruktivitis, Untuk Satuan Pendidikan Dasar dan Menengah, Jakarta: Prestasi Pustaka Publisher.

Ulfah, M. 2012. Optimalisasi Hasil Belajar IPA tentang Sistem Gerak pada Manusia Melalui Metode Diskusi dengan Tehnik Pembelajaran Tutor Sebaya. Jurnal Pendidikan Tindakan Kelas, 3(1).

Wulandari, B., \& Surjono, H. D. 2013. Pengaruh Problem-Based Learning terhadap Hasil Belajar Ditinjau dari Motivasi Belajar PLC di SMK. Jurnal Pendidikan Vokasi, 3 (2). 